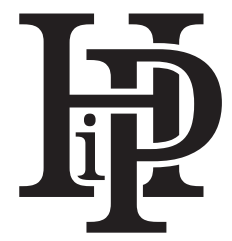

Historia i Polityka

No. 28(35)/2019, pp. 9-23

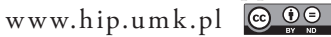

ISSN 1899-5160, e-ISSN 2391-7652

DOI: http://dx.doi.org/10.12775/HiP.2019.011

\author{
Robert $Ł O S ́$ (iD
}

University of Lodz, Faculty of International and Political Studies, Poland

\title{
Soft Power of India
}

\section{Soft power Indii}

\section{- Abstrakt •}

Indie przeżywają obecnie olbrzymi rozwój przy jednoczesnej intensyfikacji ambicji politycznych. Państwo to stara się doprowadzić do wzrostu własnej potęgi, stosując w tym celu m.in. instrumenty soft power. Indie uczą się tej sztuki na nowo, wykorzystując zasoby kultury, różnorodność religii oraz odwołując się do przeszłości.

Reorientacji uległa również polityka zagraniczna Indii, która musiała nastawić się na wsparcie gospodarki przez szukanie i utrzymanie dobrych relacji z zagranicą. Większego znaczenia nabrały wszelkie instrument związane z soft power: szczególnie dotyczy to kultury i wartości, które w połączeniu z pokojową polityką idealnie odzwierciedlały możliwości użycia soft power.

Słowa kluczowe: źródła soft power; dyplomacja publiczna

\section{- Abstract •}

India is a country experiencing tremendous economic growth while its political ambitions are aiming higher and higher as well. The country is trying to increase its global power using resources and instruments of soft power. India is learning this art anew, using its rich culture and reaching back to its past traditions. References made to religious diversity and democracy are another powerful tool in the state arsenal.

There has been a reorientation in foreign policy as well, which refocused on supporting the state's economic development by seeking and maintaining good relations with foreign countries. Soft power instruments have grown in importance, especially as concerns culture and values, which combined with peaceful policies made for a truly great opportunity of using soft power.

Keywords: soft power sources; public diplomacy 


\section{Introductory Issues: Methods and State-of-the-Art}

In studies in international relations, the category of power is one of the fundamental ones and, like many others, can be ambiguously interpreted (Kuźniar, 2005). Multiplicity of its definitions means that it is difficult to compare its scope and methods of exerting influence, which results in formation of numerous and very diverse classifications of factors building the power of a state (Pietraś, 2006; Fontana, 1993). Even if we define what power is, a large number of its determinants makes it difficult to fully grasp the concept (Wójcik, 2010).

Research on the topic of power in its broad sense has a very rich history and resulted in a vast body of literature. A significant portion of publications referenced in the present paper belong to the canon of international relations literature. Among them are the works of H. Morgenthau, R. Keohane, J. Mearsheimer, K. Waltz, W.R. Meade, E. Carr, K. Knorr, Ray S. Cline, T. Fridmann, A. Giddens, H. Kissinger, R.A. Dahl, K. Boulding, S. Colin Gray, J.S. Nye, N. Fergusson, R. Cooper, J. Kurlantzick, R. Kagan, F. Zakaria, J. Ikenberry. In Poland, contributions to research on soft power issues were made by scholars from various fields of science particularly noteworthy among the resulting literature are the works of Z. Pietraś, L. Zyblikiewicz, B. Ociepka, R. Kużniar, M. Sułek, and A. Wójcik (Łoś, 2017).

Studies focusing on soft power have a relatively short history in international relations research, but soft power instruments have been used in relations between states since forever. The new, more structured curiosity about this subject results from changes in the international environment, but also from the growing fascination with such topics as political marketing, public diplomacy or national branding. Interest in the phenomenon of soft power clearly intensified in the 1990s, and the term itself was coined and popularized by Joseph Nye Jr., who used and discussed it in several of his books (Nye, 2007; 1991; 2002; 2005; 2009; 2006). According to his definition, soft power is a type of power stemming from the domain of political values, cultural patterns and ideas, what distinguishes it from hard power, built on military strength, political violence and economic pressure.

Researchers in soft power, however, added a multitude of caveats and reservations to the concept itself and emphasized the limits of its applicability, what clearly demonstrated difficulties with defining universal principles and research methods as concerns soft power - as well as with delivering verifiable research results (Dahl, 1961; Lukes, 1974, 2008, 2007; Bachrach, 1962; Boulding, 1989).

When conducting research on soft power it is necessary to apply various research methods from the domain of social sciences. Among them, systems theory is the most valuable tool (Pietraś, 1986). Its value in the study of soft power is particularly 
high due to the need to isolate out the system while maintaining the principle of strict delimitation of its boundaries and internal structure. The systems theory and systems analysis method allows for a comprehensive approach to the studied issues, which is extremely important in particularly complex research problems (Cieślarczyk, 2011; Apanowicz, 2003). Statistical methods (Mroz-Jagiełło, 2012), which take into account both the quantitative and qualitative aspects of the phenomena studied (Michalski, 1994) are especially valuable in measurement of a state's power. In soft power research also the comparative method (analogy) is applied quite frequently due to the opportunity it offers of detecting similarities and differences between processes and phenomena (Nowak, 1985). The historical method - which is based around the principles of determinism, i.e. the assumption that all phenomena occurring in an environment are characterized by repeatability and universality, and that cause-and-effect relationships are important - is of equal significance. One must also not forget the usefulness of the behavioral method, thanks to which it is possible to follow the subjective behaviors of people and social groups (Sienkiewicz, 2010).

\section{India's Power: Hard Power Dimension}

India is classified as a superpower, meeting the criteria for such designation in a number of ways. Firstly, it is due to its surface area and population: with a population of over one billion residents India is the second most populous country in the world, after China. The country's territory covers over 3 million square $\mathrm{km}$, which puts India in the $7^{\text {th }}$ place globally. India's economy creates a GDP of more than USD 2 trillion annually and grows rapidly, but due to demographics it does not create an impressive per capita result. The Indian Army is ranked $4^{\text {th }}$ in the world overall, a result produced with multiple factors taken into consideration. Indian armed forces are currently undergoing the largest modernization effort in history, encompassing investments in national navy, ballistic missiles and nuclear weapons. For several years now, India has been the world's largest arms importer and the country is planning to expand the national arms industry in the coming years. At the same time, the Indians are aware that improving military capabilities and strengthening of the state's international position will not be possible without rapid economic growth. For this reason, India's foreign policy is focused on its key economic interests, including providing access to strategic raw materials, new technologies and capital. To achieve these goals, India must make use of its soft power resources. 
Development of a state's economy, especially as manifested in improved standards of living of the society affects its soft power to a certain degree. In this sphere India does not have a track record that can incite admiration. Since proclamation of its independence, India had an annual growth rate for a long time averaging only 3-4\% of GDP - it was not until the 1990s that a breakthrough in this trend was noted. The foundation of India's development is information technology (Nye, 2011) and this industry offers also the greatest potential for the future. The main IT center is the capital of Karnataka, Bangalore, where the Indian Institute of Science and the most important IT and electronics manufacturing companies are headquartered. Undoubtedly, the image of India is formed on the basis of successes of Indian corporations and national bodies: such as Infosys Technologies, Wipro, Tata Group, Reliance Group, Indian Institute of Management and Indian Institute of Technology. The Indian space program has also been a success - in 2006, India joined the elite club of countries that sent a mission to the Moon (Chandrayan I); the country also launched a mission to Mars and by 2020 plans to send its own manned mission to the Moon (Wiśniewski, Żodź-Kuźnia, 2008).

\section{Soft Power Resources: Culture and Cultural Diplomacy}

The culture of India is the main source of its soft power (Varma, 2007). India is considered as one of the few countries whose culture can become an alternative to Western values. The richness and diversity of Indian culture has fascinated foreigners since ancient times, attracting merchants, travelers, people fleeing religious persecution, those seeking spiritual wisdom, and finally also missionaries, foreign armies and colonizers to the country. Consequently, in the past this geographic area could boast multiple links with such distant countries as ancient Rome, Greece or Persia, not to mention the region of Southeast Asia (Wolper, 2010).

Elements of Indian pop culture, such as music and movies also have gained many fans in other countries. Indian music and movies have their own place in the global trade, and have become popular abroad, especially in Asia, Europe and Africa. Indian cinematography, associated mainly with Bollywood, produces about 1,700 films a year. Films under the Bollywood logo are sold mainly in the Asian markets, but many of them also achieve successes at international festivals (Lip$\mathrm{ka}$-Chudzik, 2009). The best example of such is the film produced in cooperation, with Great Britain Slumdog Millionaire, which won several Oscars.

In addition, the capacity of India's culture to influence other states is strengthened by the English language being spoken there - for many years after regaining 
independence in fact it served as an auxiliary language. Usage of English is all the more important in light of 122 languages and 234 dialects having been distinguished in India (Skobrtal, 2009). With that many languages around, English connects many groups, and in the global community is an important element allowing to broaden influence.

Soft power grows also thanks to literature. Indian writers, including Arundhati Roy, Kiran Desai, Aravind Adiga have won the Man Booker International Prize multiple times. The winner of the 2001 Nobel Prize in Literature was Vidiadhar Surajprasad Najpaul (Kugiel, 2014).

One of the biggest and longest-lasting Indian successes in exports is yoga, which is nowadays practiced in every corner of the world, both as a form of exercise and a tamer of stress (Kugiel, 2014). Indian cuisine with its subtle use of spices and herbs is becoming increasingly popular in the West, especially in Great Britain, which is home to many Indian expatriates (Zingerling, 1994).

Another soft power instrument is education, with programs aimed at foreigners being of particular importance. Unfortunately, the India does not have enough funds to invest in scholarships for foreign students or student exchange programs. Similarly, India has been unable to realize its potential as a tourism destination: despite the large number and diversity of monuments, it occupies a distant place in global tourist arrivals rankings.

India is also missing out on building its soft power around sports. Lack of success in this field and lack of a sports culture overall is an obstacle to the growth of Indian soft power. Also in terms of organizational capability, India is not able to efficiently organize and host large sports events. In 2010 India was the organizer of the $19^{\text {th }}$ Commonwealth Games, with the scale of its opening ceremony matching that of the Olympic Games in Beijing. The course of the games showed, however, that the event was organizationally and logistically poorly prepared (Kugiel, 2014).

The main role in protection and promotion of Indian culture is played by a public institution - the Indian Council for Cultural Relations (ICCR), established in 1950. Its mission includes formation and support for Indian culture centers and departments of Indian studies at universities abroad, granting scholarships to foreigners for studies in India, organization of cultural events and foreign trips for Indian artists. Although ICCR has a long history, it has only truly intensified its activity in the last decade, and its ambitions and expenditures have markedly increased since. Official activities of the state authorities focus on promotion of the more traditional aspects of Indian culture, which are complemented more and more effectively by activities of private entities, which translates to a popularity boost of Indian cinema and music. 


\section{Soft Power Resources: Standards and Values}

Norms and values adopted in India and largely shaped by its culture promote tolerance and acceptance of diversity. India is the birthplace of two religions - Hinduism and Buddhism. Religious diversity is associated with tolerance towards the followers of other belief systems (Bending 1996). Of great importance is Indian secularism, which in practice means harmonious coexistence of different religions - a different understanding of the term "secularism" than that dominating in the West, where rather separation of religion and state is emphasized.

Religion certainly influenced the activity of Mahatma Ghandi, who successfully built the vision of India as a country that achieved independence without resorting to violence (Herman, 1991). Thus, the set of values rooted in the religious system has been translated in India into political practice and fully recognized.

Indian support for democracy and freedom is a value that strengthens its soft power. Unlike most Asian countries, India also has a very stable and independent judiciary and, to a lesser extent, also the media. Both these institutions very often play an active role in solving important public problems.

Even if India's democracy is not perfect, it has survived despite many challenges. India has established and maintained democratic traditions, proving that such norms and values are not exclusively the domain of rich Western countries.

\section{Soft Power Resources: Foreign Policy}

Immediately after gaining independence, India in a natural progression adopted a soft power strategy based on values and peaceful coexistence. In the face of the nascent Cold War confrontation, the state did not join any of the antagonistic blocs and began to promote the "third way" in international relations and the non-alignment policy. The "five principles" of pancha shila (peaceful coexistence) established during the Bandung conference in 1955 became the foundation for the non-alignment movement, joined by multiple states. India became the voice of the Third World - a spokesman for decolonization, universal disarmament, peaceful resolution of disputes, committed to combating manifestations of racism and Western imperialism (Dixit, 2003).

What speaks in favor of India including the component of soft power in their foreign policy is the nation's lack of traditions of conquest in their relations with territories outside the Indian subcontinent (Zajączkowski, 2008). In political practice, it boils down to emphasizing that Delhi's strategy has always been a pol- 
icy of not engaging in an unjust war (Zajączkowski, 2009). That is why constant support for UN peacekeeping operations was so important for legitimization and improved credibility of India's policies; India was sending its troops abroad as part of UN-mandated missions. This active form of support for UN's main instrument in the domain of international security has also become part of Indian strategy, especially when the state strived to obtain a permanent seat on the UN Security Council.

An important task for India's diplomacy was to promote the image of India as a "responsible power" and a credible partner of the West. Hence immediately after nuclear weapons tests in May 1998 India announced a voluntary moratorium on further tests, engaged in intense dialogue with the US on the nuclear program, and in 1999 adopted a state doctrine declaring, inter alia, that they would not resort first to nuclear weapons.

Indian regional policy in the 1990s was characterized by a greater focus on soft power strategies. An examples of the use of soft power instruments was the implementation of the Gujral doctrine (Dixi, 1989), based around the concept of India's growth in power, but not at the price of weakened collaboration with neighboring countries (Zajaczkowski, 2008).

Consequently, India became engaged in a variety of activities in the region - it began cooperation with the South Asian Association for Regional Cooperation (SAARC), supporting the idea of establishing a preferential trade area. As a result of joint diplomatic activities in the region, the South Asian Preferential Trade Area (SAPTA) was created in 1995, and in 2004 the members signed an agreement establishing the South Asian Free Trade Area (SAFTA).

In year 2000 India established a strategic partnership with Russia and China. In a 2005 agreement, India gained observer status in the Shanghai Cooperation Organization. Due to the dynamic development of cooperation and increased trade between the two states, the term Chindia (Nay, 2011) was coined to describe the relationship between India and China. The intense economic exchange continues despite unresolved contentious issues and mutual concerns still surviving in the India-China relations (Zajaczkowski, 2011).

India's relations with the USA, influenced by Washington's relations with Pakistan, followed a similar path. The US-Pakistani understanding was unfavorable for India, the state becoming concerned by unregulated disputes with its western neighbor - this particularly applied to border disputes, which were accompanied by a series of armed clashes. During the last war, after the Pakistani provocation in 1999 and attacks by Pakistani terrorists on important targets in Delhi in 2001 and Mumbai in 2008, India did not decide to carry out retaliatory attacks on 
targets in Pakistan. Diplomatic talks were started, seeking a peaceful resolution to the dispute (Malone, 2011). India gained international recognition for its calm handling of the situation and striving to end the conflict with diplomatic methods (Iwanek, Burakowski, 2013).

An example of a foreign policy approach that has effectively strengthened India's soft power are its relations with Afghanistan. Since the collapse of Taliban power in this country, India has focused on humanitarian aid, supporting construction of infrastructure and providing scholarships to Afghan students. The support offered for Palestine by India under the United Nations framework was also beneficial to its image. This move gained India recognition among the Arab countries, and - importantly - also the relations between India and Israel did not deteriorate. While striving to be active in Central Asia, India supported cooperation in that region, especially with Kazakhstan and Uzbekistan, the Gulf States, Australia and Japan (Kugiel, 2014).

Despite the fact that India does not participate in the redistribution of assistance under the ODA (Official Development Assistance) fund of the OECD (Organization for Economic Cooperation and Development), the country is trying to increase its assistance to poor countries, especially in Africa. The amount of Indian aid expenditure is around USD 1.3 billion per year. The aid is granted without application of a multitude of restrictions and is purely humanitarian, which significantly increases the impact of Indian soft power (Kugiel, 2009).

\section{Soft Power Instruments: Public Diplomacy}

One of the main modern soft power tools is public diplomacy, which is a key complement to foreign policy. In 2006, a special Department of Public Diplomacy (DPD) was created in the Indian Ministry of Foreign Affairs. Its objective was to complement the promotional activities conducted by Indian embassies and the External Information Department. DPD focused mainly on relations with foreign journalists and organization of visits by important guests. In the new strategy, more attention was paid to shaping public opinion in the world and involvement in building a positive image and brand of the country. Innovations in the implementation of public diplomacy consisted mainly in the use of modern technologies and social media in reaching new audiences (Hall, 2012).

In 2010, DPD launched its own Twitter channel, a Facebook page, its own blog and a YouTube channel in order to popularize India's achievements in the spheres of economy, culture, literature and defense in an interactive way. In 2014, 
the Departments of Public Diplomacy and External Information were merged into one unit.

Public diplomacy has made a greater use of the potential of civil society and the private sector, allowing them to join forces in a wide range of activities. In 2006, the Ministry of Trade and Industry together with the Confederation of Indian Industries (CII) created a public-private partnership - India Brand and Equity Foundation (IBEF) - which began to globally promote the brand of India and attract foreign investments. The Ministry of Tourism together with private companies has been carrying out the successful IncredibleIndia promotional campaign since 2007; the same entities jointly carried out the IndiaEverywhere campaign at the Davos Economic Forum in 2006 and in the following year the India@60 program in Western Europe states. The government cooperates closely with think tanks (such as the Indian Council of World Affairs, Observer Research Foundation) in developing international contacts and presenting the Indian perspective on international affairs by organizing joint seminars, conferences, sponsoring publications and research efforts.

The national diaspora is of great importance in the development of public diplomacy and soft power. Indians living abroad are an important source of financial capital, but their political lobbying capacities are more important for soft power applications (Wolpert, 2010). In many countries people of Indian origin hold important political and administrative functions (Sahoo, Kadekar, 2012).

Indian authorities are aware of opportunities that can be created by people of Indian descent. The possibility of obtaining a Person of Indian Descent (PIO) card by citizens of another state who either themselves or whose ancestors up to the fifth generation lived in what is now India was introduced in 1998. Holders of such cards can travel to India without visas and are granted various economic privileges, such as the right to purchase real estate.

In 2004, the Ministry of Overseas Indian Affairs (MOIA) was established to provide information, partnerships and facilitations for all matters related to persons of Indian origin and non-resident Indians in main emigration countries with the goal to utilize their full potential to contribute to accelerated development of India. After the change of power in Delhi in May 2014, MOIA was incorporated into the Ministry of Foreign Affairs, but it retained its scope of tasks and some independence, including a separate post for deputy minister for diaspora (Iwanek, Burakowski, 2013). 


\section{Parametric Evaluation of India's Soft Power}

Indian potential for soft power influence is large, but has not been not fully realized in many domains. India is trying to make up for lost time and boldly engages in the development of individual areas making up the broad soft power category. Of course, there is no chance for instantaneous achievement of favorable results translating into India's increasing position in soft power rankings. Usually when evaluating soft power several areas are taken into consideration in the rankings (Łoś, 2017).

In the diplomacy category, India does not achieve extraordinary results: every state implements policies in line with their capabilities and preferences, with India naturally focusing on the region of Central and South Asia. Delhi spends significant funds on creating Indian cultural institutions abroad, while the number of diplomatic missions and national involvement in international organizations is surprisingly limited for such a large state. Actual influence of Indian political leaders is rated low in many press rankings. What testifies to the strength of India is the enormous number of active Internet users (digital diplomacy) who contribute to building up of its soft power, even if the percentage rate of public participation in digitization is not too high.

Also in the socio-political category India's track record is not very impressive. This applies particularly to indicators such as evaluation of the state system, scale of corruption and intensity of fight against it, the rule of law and efficiency of the state's policies, for all of which India is ranked at around the $100^{\text {th }}$ position globally. Rating of political and civil liberties also places India in distant positions in the rankings, but still within the limits allowing to consider it a free country. Much worse is India's score in media freedoms, where India falls already into the semi-free state category.

India is not impressive in the education category either. In university rankings, Indian universities are in distant positions, and what is important for soft power also the number of foreign students enrolled places the country only in the $27^{\text {th }}$ position in the world. The state education system at the primary and secondary level is certainly nothing to boast about, and the influence of think tanks is limited as well. As concerns rankings of Nobel prize winners in the field of exact sciences, India's showing is better: 8 Nobel prizes in three categories were awarded to Indian citizens, which gives India $11^{\text {th }}$ position in the world (China can claim only 4 Nobel Prize winners total in these categories).

In the popular culture and high culture category, India's scores are average. The Hindi language is the second most used language in the world, but as concerns it 
being learning as a second language its significance is low. The number of tourists visiting India is not too impressive, with the country ranking in the $23^{\text {rd }}$ position globally with over 14 million tourists a year. This is in clear contradiction to the state's great potential to attract tourists thanks to remainders of ancient civilization in its territory. The situation is similar with monuments on the UNESCO cultural heritage list. Despite the potential being there, there are no known and widely visited museums in India. The country is the global leader in the number of produced films, but on the other hand it is entirely unable to use sports as a public diplomacy resource.

In the socio-economic category, India has enormous potential. Large Indian companies continue to build their brands while at the same time strengthening the state's brand and image. Nevertheless, in terms of competitiveness of the economy the country does not meet the expectations - India occupies the $41^{\text {st }}$ position in this category. India's innovation index places the state even further in the rankings - in the $29^{\text {th }}$ place. Despite its economic growth, India has much to do in improving the standard of living of its citizens; India's Human Development Index (HDI) index puts it only in the $131^{\text {th }}$ position in the world. Its Gini index which assesses the level of social inequality - is slightly better, with India ranking in $40^{\text {th }}$ place globally.

Diagram 1. Indiass soft power rating in various categories in comparison with scores of the USA and China

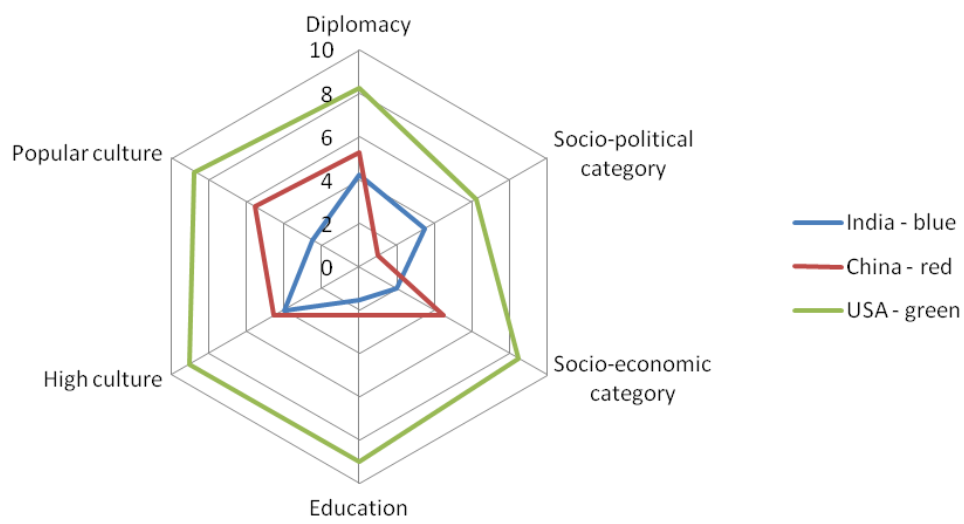

Source: Łoś, 2017.

Soft power index of the USA, despite many shortcomings, is still the best in the world and India of course cannot dream of competing on equal footing with 
the global power in this domain. The possibility of catching up to and competing with China in soft power scores looks more promising. Here, India has greater chances of developing mechanisms sufficiently improving the overall impact of its soft power, which would be particularly important for India in the Central and South Asian region. However, this effort would of course require establishment and implementation of a strategy with soft power at its core.

Table 1. Soft power index of selected states

\begin{tabular}{|c|c|c|}
\hline Ranking & State & Points awarded (max.60) \\
\hline 1 & USA & 49,50 \\
\hline 2 & Great Britain & 44,00 \\
\hline 3 & Germany & 40,50 \\
\hline 4 & France & 39,75 \\
\hline 5 & Sweden & 30,50 \\
\hline 6 & Holland & 28,75 \\
\hline $7-8$ & Italy, Canada & 27,50 \\
\hline 9 & Denmark & 27,00 \\
\hline 10 & Finland & 25,75 \\
\hline 11 & Switzerland & 25,25 \\
\hline $12-13$ & Austria, Spain & 24,00 \\
\hline 14 & Japan & 23,50 \\
\hline 15 & China & 23,00 \\
\hline 16 & Australia & 22,50 \\
\hline 17 & Norway & 22,25 \\
\hline 18 & Belgium & 21,00 \\
\hline 19 & Poland & 20,00 \\
\hline 20 & Czech Republic & 17,50 \\
\hline $21-22$ & Russia, New Zealand & 16,75 \\
\hline $23-24$ & Ireland, South Korea & 15,25 \\
\hline 25 & Luxemburg & 14,00 \\
\hline 26 & Brasil & 11,00 \\
\hline $27-28$ & Iceland, Singapore & 10,75 \\
\hline 29 & India & 10,00 \\
\hline 30 & Portugal & 9,50 \\
\hline
\end{tabular}

Source: Łoś, 2017. 


\section{Soft Power Limitations. Conclusion}

Despite successes in the field of technical progress, India is not a country of prosperity, which makes it unable to serve as a model of social development for other countries. Undoubtedly, significance of India's economy has increased, but it has not eliminated poverty in Indian society. On the one hand, India boasts worldclass institutes of technology and management, but it still remains unable to provide even basic education for a large portion of its population.

The challenge for soft power capabilities of India is its complex social system. This applies in particular to information about rape and violence against women widespread in the media, conservatism and patriarchism of Indian society, or the custom of arranged marriages. A big stain in the national image of peaceful and tolerant culture are pogroms and riots caused by religious differences. Violations of human rights by state authorities also contribute to this negative picture of India, which defines the limits of its soft power (Skobrtal, 2009).

The fact that members of the governing elite in India realize the necessity of using soft power was clearly demonstrated in the electoral manifesto of BJP (Bharatiya Janata Party, Indian People's Party), in power since the 2014 elections. This manifesto emphasized the importance of soft power in foreign policy and announced the adoption of a more active style of diplomacy, especially making use of and emphasizing its spiritual, cultural and philosophical dimension (Kugiel, 2014). One of the goals of this political program was strengthening of India's image by using the power of 5 Ts: tradition, talent, tourism, trade and technology.

\section{References:}

Apanowicz, M. (2003). Metodologia nauk. Toruń: Wydawnictwo Naukowe UMK.

Arundhati, R. (2012). Indie rozdarte. Warszawa: Wydawnictwo Wielka Litera.

Bachrach, P. Baratz, M. (1962). Two Faces of Power. The American Political Science Review, 56(4), 947-952.

Bending, A.H. (1996). The Making of Foreign Policy. Baltimore: Johns Hopkins University Press.

Boulding, K. (1989). Three Faces of Power. London: SAGE.

Cieślarczyk, M. (2011). Teoretyczne i metodologiczne podstawy badania problemów bezpieczeństwa i obronności państw. Siedlce: Akademia Podlaska.

Cooper, R.N. (2005). Pękanie granic. Porzadek i chaos w XXI wieku. Poznań: Media Rodzina.

Dahl, R.A. (1961). Who Governs: Demokracy and Power in an American City. New Haven: Yale University Press. 
Dixit, J.N. (2003). India's Foreign Policy: 1947-2000. New Delhi: Picus Books.

Ferguson, N. (2004). Colossus. The Rise and Fall of the American Empire. London: Penguin Random House.

Fontana, B. (1993). Hegemony and Power: on the Relation Between Gramsci and Machiavelli. London: Prison Notebooks.

Global Fire Power. (2017). Retrieved from: https://www.globalfirepower.com.

Hall, I. (2012). India's New Public Diplomacy: Soft Power and the Limits of Government Action. Asian Survey, 52(6), 21-34.

Herman, A.L. (1991). A Brief Introduction to Hinduism. San Francisko: Kindle Edition.

Retrieved from: http://esa.un.org/unpd/wpp/Download/Standard/Population/.

Ikenberry, J.G. (2000). After Victory. Institutions, Strategic Restraint and the Rebuilding of Order after Major Wars. London: Paperback.

Iwanek, K., Burakowski, A. (2013). Indie. Od kolonii do mocarstwa 1857-2013. Warszawa: Wydawnictwo PWN.

Kagan, R. (2009). Powrót historii i koniec marzeń. Poznań: Wydawnictwo REBIS.

Kagan, R. (2003). Potęga i raj. Ameryka i Europa w nowym porządku świata. Warszawa: Wydawnictwo Studio EMKA.

Kugiel, P. (2009). Na drodze ku potędze: polityka zagraniczna Indii. Polski Przegląd Międzynarodowy, 6, 224-253.

Kugiel, P. (2014). Soft power w indyjskiej polityce zagranicznej. Sprawy Międzynarodowe, 3, 122-145.

Kuźniar, R. (2005). Polityka i siła. Studia strategiczne. Zarys problematyki. Warszawa: Wydawnictwo Naukowe Scholar.

Lipka-Chudzik, K. (2009). Bollywood dla początkujacych. Warszawa: Wydawnictwo Prószyński i S-ka.

Lukes, S. (2007). Power and the Battle for Hearts and Minds: On the Bluntness of Soft power. In: F. Berenskoetter, M.J. Williams (eds.). Power in World Politics (p. 76-98). London: Paperback.

Lukes, S. (2008). The Power to Lead. New York: University Press.

Lukes, S. (1974). Power, A Radical View. London: Paperback.

Łoś, R. (2017). Soft power we wspótczesnych stosunkach międzynarodowych. Łódź: Wydawnictwo Uniwersytetu Łódzkiego.

Michalski, T. (1994). Statystyka. Warszawa: Wydawnictwa Szkolne i Pedagogiczne.

Morgenthau, H. (1948). Politics Among Nations. The Struggle for Power and Peace. New York: Brief Edition.

Mroz-Jagiełło, A. Wolanin, A. (2012). Współzależność obszarów badań nauki o bezpieczeństwie i nauki obronności. Obronność - Zeszyty Naukowe Wydziału Zarządzania i Dowodzenia Akademii Obrony Narodowej, 2, 75-88.

Nowak, S. (1985). Metodologia nauk społecznych. Warszawa: Wydawnictwo PWN.

Nye, J.S. (2006). Think Again: Soft Power. Foreign Policy, 3, 23-37.

Nye, J.S. (2007). Soft Power. Jak osiagnać sukces w polityce światowej. Warszawa: Wydawnictwo Akademickie i Profesjonalne.

Nye, J.S. (2002). The Paradox of American Power. Oxford: Oxford University Press. 
Nye, J.S. (2005). Soft Power. The Means to Success In World Politics. New York: Public Affairs.

Nye, J.S. (1991). Bound to Lead. The Changing Nature of American Power. New York: University Press.

Nye, J.S. (2009). Konflikty międzynarodowe. Wprowadzenie do teorii i historii. Warszawa: Wydawnictwo Akademickie i Profesjonalne.

Nye, J.S. (2011). The Future of Power. New York: Public Affairs.

Ociepka, B. (2002). Komunikowanie międzynarodowe. Wrocław: Wydawnictwo Astrum.

Pietraś, Z. (1986). Podstawy teorii stosunków międzynarodowych. Lublin: Wydawnictwo UMCS.

Pietraś, M. (2006). Pozimnowojenny ład międzynarodowy. In: M. Pietraś (ed.). Międzynarodowe stosunki polityczne (p. 290-310). Lublin: Wydawnictwo UMCS.

Pietrzak, J. (2016). Najpopularniejsza kinematografia świata. Skąd się bierze potęga Bollwood. Retrieved from: www.ecriture.com.pl/articles/80/80.pdf.

Sahoo, A.K., Kadekar, L.N. (2012). Global Indian Diaspora. History, Culture, Identity. New Delhi: Rawat Publications.

Sienkiewicz, P. (2010). Metodologia badań bezpieczeństwa narodowego: „Bezpieczeństwo 2010”. Warszawa: Wydawnictwo UW.

Skobrtal, M. (2009). Różnorodność językowa a federalizm w Indiach. In: A. Potyrała, M. Skobrtala (eds.). Indie w XXI wieku. Wybrane problemy. Poznań: Wydawnictwo UAM.

Varma, P.K. (2010). Culture as an Instrument of Diplomacy. In: A. Sinha, M. Mohta (eds.). Indian Foreign Policy: Challenges and Opportunities (p. 34-56). New Delhi: Rawat Publications.

Wiśniewski, J., Żodź-Kuźnia, K. (2008). Mocarstwa wspótczesnego świata. Problem przywództwa światowego. Poznań: Wydawnictwo Naukowe UAM.

Wolpert, S. (2010). Nowa historia Indii. Warszawa: Książka i Wiedza.

Wójcik, A. (2010). Dylemat potęgi: praktyczna teoria stosunków międzynarodowych. Warszawa: Wydawnictwo UW.

Zajączkowski, J. (2009). Strategia Międzynarodowa Indii wobec Chin i Rosji na początku XXI wieku. In: T. Kapuśniak (ed.). Strategiczny trójkąt Rosja-Chiny-Indie. Szanse i wyzwania w XXI wieku (p. 45-64). Lublin: Wydawnictwo UMCS.

Zajączkowski, J. (2008). Indie w stosunkach międzynarodowych. Warszawa: Wydawnictwo Naukowe Scholar.

Zakaria, F. (1998). From Wealth to Power: The Unusual Origins of America's World Role. Princeton: Paperback.

Zingerling, C. (1994). Kuchnia indyjska. Warszawa: Agencja Wydawnicza Jerzy Mostowski. 